\title{
Pengaruh Relaksasi Dzikir terhadap Tingkat Kecemasan Pasien Gagal Ginjal Kronis yang Menjalani Hemodialisa
}

\author{
Iin Patimah ${ }^{1}$, Suryani ${ }^{2}$, Aan Nuraeni ${ }^{2}$ \\ ${ }^{1}$ STIKes Karsa Husada Garut, ${ }^{2}$ Fakultas Keperawatan Universitas Padjadjaran \\ E-mail:ynsuryani@yahoo.com
}

\begin{abstract}
Abstrak
Salah satu permasalahan psikologis yang paling sering ditemukan pada pasien gagal ginjal kronis (GGK) yang menjalani hemodialisis yaitu cemas. Kecemasan yang tidak diatasi dapat mengakibatkan dampak negatif untuk pasien. Salah satu intervensi nonfarmakologis untuk mengurangi kecemasan, yaitu dengan teknik relaksasi. Teknik relaksasi yang digunakan dalam penelitian ini adalah relaksasi dzikir, yaitu suatu metode yang memadukan antara relaksasi dan dzikir dengan fokus latihan pada relaksasi dan kata yang terkandung di dalam dzikir yang dapat memunculkan respon relaksasi. Tujuan penelitian ini adalah untuk melihat pengaruh relaksasi dzikir terhadap kecemasan pada pasien GGK yang menjalani hemodialisis di RSUD dr. Slamet Garut. Metode penelitian menggunakan pre experimental one group pre and post test design dengan jumlah sampel 17 responden yang diambil berdasarkan teknik purposive sampling. Penelitian ini mengukur skor kecemasan menggunakan instrument HAM-A (Hamilton Anxiety) sebelum dan sesudah intervensi relaksasi dzikir. Relaksasi dzikir dilaksanakan dua kali dalam sehari selama 2 hari, selanjutnya data dianalisa menggunakan uji t. Hasil penelitian menunjukan terdapat perbedaan yang bermakna antara tingkat kecemasan sebelum dan sesudah intervensi $(\mathrm{p}<0.005)$. Relaksasi dzikir berdampak positif dalam menurunkan tingkat kecemasan pasien GGK yang menjalani hemodialisis. Penggunaan relaksasi dzikir dapat dipertimbangkan sebagai salah satu intervensi keperawatan untuk mengatasi kecemasan pada pasien GGK yang menjalani hemodialisis di RSUD dr. Slamet Garut.
\end{abstract}

Kata kunci: Dzikir, gagal ginjal kronis, hemodialisis, kecemasan, relaksasi.

\section{The Impact of Dzikir to The Level of Anxiety of Chronic Renal Failure Patient Undergoing Hemodialysis}

\begin{abstract}
Anxiety disorder can be adversely impacting to the chronic renal failure (CRF) patients undergoing hemodialysis. Untreated anxiety could affect negatively both physiological and psychological and exacerbate the disorder. Dzikr relaxation is a methode that combines relaxation and repetitious of prayer (dzikr) which focused on relaxation technique and the words contained in the dzikr can be a non-pharmacological intervention to reduce anxiety with leading relaxation respons. Thus, the purpose of this study was to examine the effect of dzikr relaxation intervention to the anxiety level of CRF patients undergoing hemodialysis in dr. Slamet Garut Hospital. Method and Design this research involving 17 participants, taken through purposive sampling, completed dzikr relaxation twice a day for two days period. Hamilton Anxiety Rating Scale (HAM-A) was used to assess anxiety level both before and after treatment. Current study used One-group pretest-posttest design and T-test was used for the analysis by the time all data have been completely gathered. The result showed there was a significant contrast of anxiety level for all participants before and after dzikr intervention $(\mathrm{P}<0.005)$. The average of participant anxiety scores is 18 (mild to moderate anxiety) before treatment whereas found 13 point (mild) in average for anxiety score post treatment. The anxiety scores decreased 3 to 6 points from initial scoring subsequent to participants completed dzikr relaxation. Dzikr relaxation can be considered as one of nursing intervention in mitigating anxiety disorder for CRF patients during hemodialysis treatment in dr. Slamet Garut Hospital.
\end{abstract}

Key words: Anxiety, Chronic Renal Failure, dzikr, hemodialysis, relaxation. 
Iin Patimah: Pengaruh Relaksasi Dzikir terhadap Tingkat Kecemasan Pasien Gagal Ginjal

\section{Pendahuluan}

Salah satu permasalahan psikologis utama yang sering muncul pada pasien GGK yang menjalani hemodialisis yaitu cemas (Mahdavi, Gorji, Gorji, Yazdani \& Ardebil, 2013). Cemas merupakan respon emosional yang tidak menyenangkan terhadap berbagai macam stressor baik yang jelas maupun tidak teridentifikasikan yang ditandai dengan adanya perasaan khawatir, takut, serta adanya perasaan terancam (Kaplan \& Sadock, 2003).

Penelitian sebelumnya yang dilakukan di RSUD dr. slamet garut di Unit Hemodialisis Rumah Sakit Umum Daerah (RSUD) dr. Slamet Garut didapatkan data dari 61 responden didapatkan hasil 1 pasien (3\%) mengalami panik, 11 pasien (18\%) mengalami kecemasan berat, 43 pasien (70\%) mengalami kecemasan sedang dan 6 pasien mengalami kecemasan ringan (9\%) (Aris, 2011). Kecemasan yang tidak teratasi dapat menimbulkan beberapa dampak diantaranya seseorang cenderung mempunyai penilaian negatif tentang makna hidup, penurunan kualitas hidup, perubahan emosional seperti depresi kronis serta gangguan psikosa (Cukor, Coplan, Brown, \& Friedman, 2008; Najmuddin, 2006). Kecemasan yang dialami pasien GGK yang menjalani hemodialisis dapat disebabkan oleh berbagai stressor, diantaranya: pengalaman nyeri pada daerah penusukan fistula saat memulai hemodialisis, komplikasi hemodialisis, ketergantungan pada orang lain, kesulitan dalam mempertahankan pekerjaan, finansial, ancaman kematian perubahan konsep diri, perubahan peran serta perubahan interaksi sosial (Finnegan, Jennifer \& Veronica, 2013; De Sousa, 2008; Wang \& Chen, 2009; Santoso. 2005; Smeltzer \& Bare, 2002)

Stressor yang menyebabkan cemas pada pasien GGK cenderung menetap, oleh karena itu diperlukan suatu strategi yang efektif, efisien, dan mudah dilakukan untuk mampu mengurangi kecemasan sehingga pasien mampu beradaptasi terhadap stressor yang ada. Salah satu strategi efektif untuk mengatasi kecemasan yaitu dengan teknik relaksasi. Teknik relaksasi yang digabungkan dengan unsur keyakinan kepada agama serta kepada Tuhan dapat meningkatkan respon relaksasi lebih kuat dibandingkan hanya teknik relakasasi saja (Benson, 2000).

Salah satu pendekatan keyakinan spiritual dalam agama Islam yaitu dengan teknik mengingat Allah atau berdzikir. Beberapa penelitian menunjukkan efektivitas dzikir terhadap berbagai kondisi dan subjek penelitian, seperti kecemasan pada pasien AMI (Acute Myocardial Infarction) (Mardiyono, Songwathana \& Petpichetchian, 2011), kecemasan pasien pre operasi bedah mayor (Mardiyono, Angraeni, \& Sulistyowati, 2007), nyeri serta kecemasan pada pasien yang menjalani operasi abdomen (Soliman, 2013) serta menurunkan intensitas halusinasi dengar pada pasien dengan gangguan mental kronis (Suryani, 2013).

Adapun pelaksanaan relaksasi dzikir yang dikutip dalam penelitian Yanti (2012) melalui tahapan sebagai berikut: berwudhu, mencari suasana yang tenang dan duduk dengan rileks, melakukan teknik nafas dalam, melakukan peregangan otot, setelah itu mengucapkan beberapa kalimat dzikir baik secara lisan maupun qolbu (dalam hati) serta diakhiri dengan bacaan Alhamdulilah. Dalam melaksanakan relaksasi dzikir sebetulnya dapat dilaksanakan kapanpun dan tidak ada batasan waktu. Namun menurut Benson (2000) pelaksanaan relaksasi lebih baik dilakukan sebelum makan, hal ini dilakukan untuk menghindari agar proses pelaksanaan relaksasi tidak terganggu oleh sistem pencernaan.. Adapun durasi waktu yang dibutuhkan untuk pelaksanaan dzikir sebetulnya tidak ada batasan waktu, namun berdasarkan penelitian yang dilakukan Mardiyono, Songwathana \& Petpichetchian, (2011) pelaksanaan dzikir untuk mengurangi kecemasan pasien AMI dilakukan selama 25 menit. Menurut Greenberg (2002) dalam bukunya menyebutkan bahwa teknik relaksasi akan memberikan hasil berupa respon relaksasi, setelah dilakukan minimal sebanyak tiga kali latihan. Berdasarkan pendapat diatas dan atas pertimbangan kunjungan pasien ke unit hemodialisa yaitu seminggu dua kali dengan rentang 2 hari antara hemodialisa pertama dan kedua. Maka pada penelitian ini akan dilakukan relaksasi dzikir sebanyak 4 kali latihan.

Relaksasi yang dilakukan mampu menimbulkan respon relaksasi berupa perasaan nyaman dengan indikator perubahan 
Iin Patimah: Pengaruh Relaksasi Dzikir terhadap Tingkat Kecemasan Pasien Gagal Ginjal

secara klinis berupa: penurunan tekanan darah, respirasi dan konsumsi oksigen (Park dkk., 2013). Ditambahkan menurut Subandi (2009) bacaan dzikir mampu menenangkan, membangkitkan percaya diri, kekuatan, perasaan aman, tentram, dan memberikan perasaan bahagia. Secara medis juga diketahui bahwa orang yang terbiasa berdzikir mengingat Allah secara otomatis otak akan berespon terhadap pengeluaran endorphine yang mampu menimbulkan perasaan bahagia dan nyaman (Suryani, 2013; Ayashi, 2012). Penelitian ini bertujuan untuk mengidentifikasi apakah ada pengaruh relaksasi dzikir terhadap tingkat kecemasan pasien GGK yang menjalani hemodialisis.

\section{Metode Penelitian}

Rancangan penelitian yang digunakan pada penelitian ini yaitu pre experimental one group pre and posttest design. Dalam penelitian ini intervensi untuk menurunkan kecemasan dengan menggunakan teknik relaksasi dzikir.

Teknik pengambilan sampel dalam penelitian ini menggunakan purposive sampling, yaitu menetapkan sampel yang sesuai dengan kriteria inklusi. Hasil perhitungan didapatkan besar sampel sebanyak 17 responden dengan kriteria inklusi: beragama Islam; mengalami cemas ringan dan sedang dimana sebelumnya diukur dengan instrumen HAM-A; dapat menulis dan membaca; pasien dalam kondisi sadar, dapat berorientasi pada orang, tempat dan waktu; memiliki lingkungan yang mendukung (memiliki ruangan/kamar sendiri) untuk melakukan terapi; bersedia menjadi responden. Adapun yang menjadi kriteria eksklusi antara lain: pasien GGK yang sedang menjalani rawat inap; pasien ketika menjalani terapi mendapatkan kejadian tidak terduga dan diluar kebiasaan yang dapat meningkatkan dan menurunkan kecemasan pada saat dilakukan intervensi, seperti: rencana operasi, ada keluarga meninggal/ sakit, berita gembira.

Instrumen yang digunakan pada penelitian ini menggunakan kuesioner serta instrumen skala kecemasan. Kuesioner berisikan pertanyaan tentang karakteristik responden diantaranya: usia, jenis kelamin, pendidikan, pekerjaan, status perkawinan, lamanya menjalani hemodialisis, frekuensi menjalani hemodialisis serta ketergantungan pasien. Instrument lain yang digunakan yaitu skala kecemasan dengan menggunakan Hamilton rating scale for anxiety (HAM-A).

HAM-A terdiri dari 14 pertanyaan yang berisikan mengenai perasaan cemas, ketegangan, ketakutan, sulit tidur, keluhan fisik dan perilaku. Rentang nilai pertanyaan tiap item pada HAM-A dari 0-4 dan total skornya 56. Dimana skor nya akan diinterpretasikan sebagai berikut : kecemasan ringan kurang dari 17, kecemasan sedang 18-24 serta kecemasan berat 25-30. Beberapa uji validitas dan reliabilitas telah dilakukan untuk membuktikan ketepatan instrument HAM-A. HAM-A memiliki tingkat reliabilitas cukup tinggi yaitu 0.81 dan interval scale correlation adalah 0.65, sedangkan untuk nilai validitas alat ini sebesar 0.77 .

Pelaksanaan relaksasi dzikir pada penelitian ini dilaksanakan selama 2 hari, dalam satu hari dilakukan selama 2 sesi masing masing sesi selama 25 menit. Pengambilan responden penelitian dilakukan di ruang hemodialisa $d r$. Slamet garut. Responden yang sesuai dengan kriteria inklusi selanjutnya diberikan penjelasan prosedur penelitian serta informed concent. Tahapan berikutnya peneliti akan mengunjungi responden selama 2 hari berturut turut, dalam satu hari dilakukan dua pertemuan pagi jam 09.00 dan sore jam 16.00 WIB. Relaksasi dzikir dilaksanakan di rumah responden serta didampingi oleh observer yaitu peneliti ataupun asisten peneliti dengan menggunakan panduan protokol yang telah disiapkan. Adapun tahapan pelaksanaan relaksasi dzikir dengan cara memastikan lingkungan atau suasana yang tenang, pasien diminta duduk ataupun tidur dengan rileks, melakukan teknik relaksasi nafas dalam dilanjutkan dengan teknik relaksasi otot, kemudian tahapan terakhir pasien mengucapkan beberapa kalimat dzikir yaitu Allah, Subhanallah, Alhamdulilah, Allahu Akbar, Lahaula wala quwwata illa billah. Kalimat dzikir tersebut diucapkan baik secara lisan maupun qolbu. Setelah lengkap melaksanakan relaksasi dzikir selama 4 sesi 
Iin Patimah: Pengaruh Relaksasi Dzikir terhadap Tingkat Kecemasan Pasien Gagal Ginjal

latihan peneliti mengukur kembali tingkat kecemasan responden dengan instrumen HAM-A Kembali.

\section{Hasil Penelitian}

Karakteristik Responden diketahui dari 17 reponden sebagian besar berada pada rentang usia dewasa pertengahan (41-60 tahun) $(\mathrm{n}=12 ; 76 \%)$; berjenis kelamin perempuan $(\mathrm{n}=9 ; 52,9 \%)$ mempunyai latar belakang pendidikan rendah (SD, SMP SMA) $(n=15$; $88,2 \%)$ responden tidak bekerja $(\mathrm{n}=10$; $58,2 \%)$; sudah menikah ( $\mathrm{n}=16 ; 94,1 \%)$; mengalami ketergantungan terhadap anggota keluarga $(n=14 ; 82,4 \%)$; menjalani hemodialisis 2 kali dalam seminggu ( $n=16$; 94,1\%); telah menjalani hemodialisis lebih dari 2 tahun ( $\mathrm{n}=9$; 52,9\%).

Gambaran kecemasan pasien sebelum dan setelah intervensi relaksasi dzikir

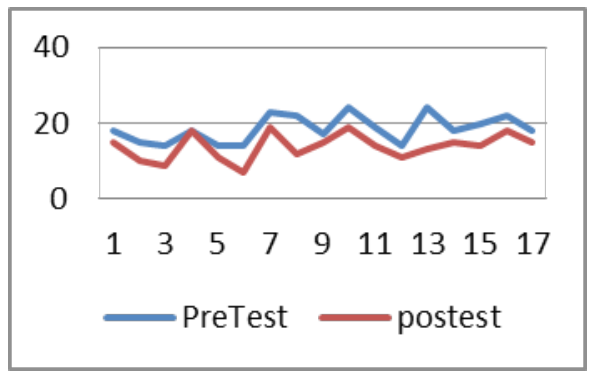

\section{Gambar 1 Tingkat Kecemasan Responden Sebelum dan setelah Dilakukan Intervensi Relaksasi Dzikir}

Dilihat dari diagram diatas dapat terlihat adanya perbedaan score kecemasan sebelum dan setelah dilakukan intervensi relaksasi dzikir dimana pada garis post test yaitu setelah dilakukan relaksasi dzikir cenderung score kecemasan menurun.

Berdasarkan hasil uji normalitas data yang telah dilakukan sebelumnya, diketahui data kecemasan sebelum dan sesudah dilakukan intervensi berdistribusi normal yaitu $\mathrm{p}=0.079$ untuk kecemasan sebelum intervensi dan p $=0.572$ setelah dilakukan intervensi. Selanjutnya untuk melihat perbedaan rerata tingkat kecemasan sebelum dan sesudah intervensi menggunakan analisis bivariat yaitu dengan uji t berpasangan. Berikut disajikan perbedaan rerata tingkat kecemasan sebelum dan sesudah intervensi.

Tabel 1 Perbedaan Rerata Tingkat Kecemasan Sebelum dan Sesudah Intervensi

\begin{tabular}{cccccc}
\hline $\begin{array}{c}\text { Skala } \\
\text { Pengukuran }\end{array}$ & $\begin{array}{c}\text { Ke- } \\
\text { lompok }\end{array}$ & Rerata & SD & P & CI 95 \% \\
\hline Kecemasan & Sebelum & 18,47 & 3,6 & 0.000 & $(3,23)-(6,05)$ \\
& Sesudah & 13,82 & 3,52 & & \\
\hline
\end{tabular}

Hasil uji statistik perbedaan rerata tingkat kecemasan sebelum dan sesudah intervensi menunjukan terdapat perbedaan rerata tingkat kecemasan sebelum dan sesudah intervensi dengan nilai $\mathrm{p}=0.000$ yang berarti ada pengaruh positif relaksasi dzikir terhadap kecemasan pasien GGK yang menjalani hemodialisis.

\section{Pembahasan}

Seseorang yang sedang mengalami cemas, cenderung mengalami perubahan persepsi dan memiliki pikiran negatif terkait permasalah yang dihadapinya (Stuart \& Sundeen, 2006; Paul dkk., 2008). Jika seorang selalu berpikiran negatif maka ada beberapa dampak diantaranya: menurunnya status kesehatan, menurunnya fungsi adaptasi seseorang terhadap perubahan lingkungan, sikap pesimistik terhadap masa depan dan kecenderungan depresi serta penurunan kualitas hidup (Palos \& Viscu, 2014). Selain itu pikiran negatif akan menstimulasi otak bagian prefrontal korteks untuk berusaha memfokuskan terhadap permasalah yang sedang dihadapi, sehingga seseorang akan lebih berfikiran negatif lagi terhadap permasalahan yang dialami (Bherking \& Whitley, 2008). Oleh karena itu diperlukan suatu intervensi yang dapat memutuskan siklus pikiran negatif yang dialami individu yang sedang mengalami cemas. Teknik pemusatan pikiran terhadap kalimat-kalimat positif ternyata mampu untuk memutuskan siklus pikiran negatif seseorang (Newberg \& Waldman, 2013).

Teknik pemusatan pikiran dapat dilakukan melalui teknik relaksasi dzikir. Pelaksanaan teknik relaksasi dzikir pada penelitian berupa 
Iin Patimah: Pengaruh Relaksasi Dzikir terhadap Tingkat Kecemasan Pasien Gagal Ginjal

penggabungan teknik relaksasi dengan bacaan dzikir yang diulang-ulang. Bacaan dzikir yang diulang-ulang merupakan salah satu cara untuk memusatkan pikiran seseorang terhadap makna dari kalimat dzikir. Kalimat dzikir sendiri mengandung makna positif, sehingga pikiran negatif yang dialami seseorang yang cemas akan digantikan dengan pikiran positif ketika orang tersebut berfokus pada kalimat dzikir. Dzikir pada beberapa penelitian dapat menurunkan kecemasan, seperti kecemasan pada pasien AMI (Acute Myocardial Infarction) (Mardiyono, Songwathana \& Petpichetchian, 2011), kecemasan pasien pre operasi bedah mayor (Mardiyono, Angraeni, \& Sulistyowati, 2007), nyeri serta kecemasan pada pasien yang menjalani operasi abdomen (Soliman, 2013).

Makna yang terkandung dari kalimat dzikir Allah, Subhanallah, Alhamdulilah, Allahu Akbar, Lahaula wala quwwata illa billah, antara lain: bentuk kepasrahan seseorang terhadap Tuhannya, sehingga akan memunculkan harapan dan pandangan positif terhadap kehidupan serta memberikan ketenangan jiwa (Newberg \& Waldman, 2013); bentuk permohonan taubat kepada Tuhan sehingga akan menguatkan seseorang dalam menghadapi tantangan yang akan terjadi seperti kematian dan komplikasi akibat sakit yang dialami (Nuraeni, 2012); bentuk rasa syukur kepada Tuhan, sehingga dengan bersyukur senantiasa berpikiran positif, selalu melihat sesuatu dari sisi positif, memberi makna positif dari setiap kejadian, dan bersabar terhadap kesulitan (Sukaca, 2014). Ketika seseorang selalu mengucapkan kalimat positif maka kalimat positif diyakini mampu untuk menghasilkan pikiran serta emosi positif (Newberg \& Waldman, 2013). Emosi positif mampu merangsang kerja limbic untuk menghasilkan endorphine. Endorphine mampu menimbulkan perasaan euforia, bahagia, nyaman, menciptakan ketenangan dan memperbaiki suasana hati (mood) seseorang hingga membuat seseorang berenergi (Suryani, 2013; Ayashi, 2012)

Agar seseorang fokus terhadap kalimat dzikir yang diucapkan, maka sebelum membaca kalimat dzikir dilakukan teknik relaksasi dengan cara; memilih posisi rileks, melakukan teknik nafas dalam, serta melemaskan seluruh otot tubuh. Dilihat dari aspek fisiologis relaksasi dapat menurunkan kecemasan melalui mekanisme peningkatan kerja saraf parasimpatis dengan menghambat kerja saraf simpatis. Mekanisme ini dapat dilihat di gambar dibawah ini:

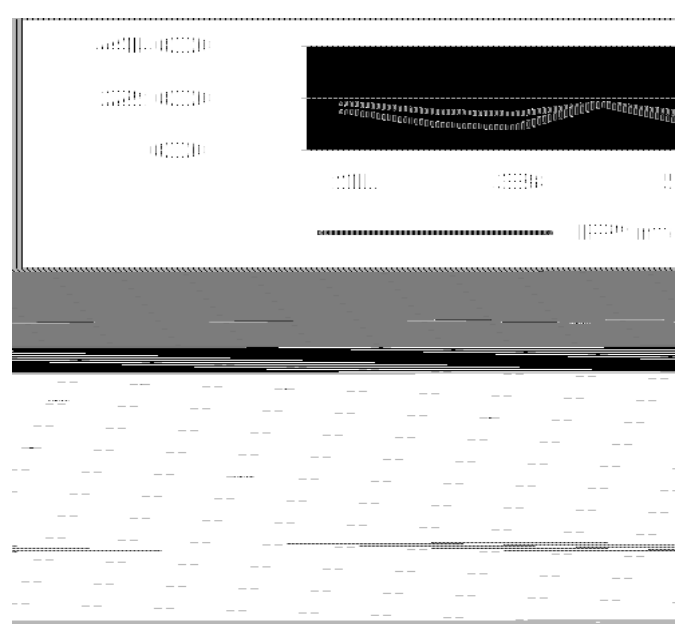

\section{Gambar 2 Respon Stress dan Respon Relaksasi}

Ketika seseorang merasa cemas maka sistem tubuh akan bekerja dengan meningkatkan kerja saraf simpatis sebagai respon terhadap stres. Sistem saraf simpatis bekerja melalui aktivasi medula adrenal untuk meningkatkan pengeluaran epinephrine, norepinephrine, cortisol serta menurunkan nitric oxide. Keadaan tersebut akan menyebabkan perubahan respon tubuh seperti peningkatan denyut jantung, pernafasan, tekanan darah, aliran darah ke berbagai organ meningkat serta peningkatan metabolisme tubuh. Untuk menghambat kerja saraf simpatis dapat dilakukan dengan meningkatkan aktivasi kerja saraf parasimpatis untuk menimbulkan respon relaksasi.

Respon relaksasi yang ditimbulkan oleh saraf parasimpatis bekerja dengan cara menstimulasi medula adrenal untuk menurunkan pengeluaran epinephrine, norepinephrine, cortisol serta meningkatkan nitric oxide. Keadaan tersebut akan menyebabkan perubahan respon tubuh seperti penurunan denyut nadi, tekanan darah, konsumsi oksigen, metabolisme tubuh, produksi laktat dan seseorang merasakan perasaan nyaman (Benson, 2000; Park, dkk., 
Iin Patimah: Pengaruh Relaksasi Dzikir terhadap Tingkat Kecemasan Pasien Gagal Ginjal

2013). Apabila secara fisik kondisi tubuh sudah rileks, maka kondisi psikisnya juga merasakan perasaan tenang (Yamamoto \& Nagata, 2011). Salah satu teknik untuk meningkatkan kerja parasimpatis yaitu dengan teknik relaksasi (Benson, 2000). Teknik relaksasi nafas dalam dan otot merupakan jenis relaksasi yang dapat digunakan untuk meningkatkan kerja parasimpatis (Catherine \& King, 2013)

Teknik relaksasi yang digabungkan dengan bacaan dzikir mampu menimbulkan respon relaksasi sehingga dapat menurunkan kecemasan. Hal ini sejalan dengan hasil penelitian ini bahwa dengan intervensi relaksasi dzikir dapat menurunkan kecemasan pasien GGK yang menjalani hemodialisis. Intervensi relaksasi dzikir untuk menurunkan kecemasan klien sangat relevan dengan peran perawat. dalam melaksanakan peran dalam memberikan asuhan keperawatan, perawat seharusnya melihat dari semua aspek yang dimiliki pasien meliputi: aspek biologi, psikologi, sosial, dan spiritual (Perry \& Potter, 2005). Pendekatan relaksasi dzikir terhadap pasien GGK memandang unsur spiritual pasien, dimana seseorang dengan penyakit kronis cenderung berupaya memperkuat aspek spiritualnya. Hal ini akan mendukung keberhasilan teknik relaksasi dzikir untuk pasien penyakit kronis salah satunya penyakit gagal ginjal, dalam hal ini perawat sangat berperan penting dalam memberikan asuhan keperawatan dengan pendekatan spiritual melalui proses keperawatan (Mauk \& Schmidt, 2004).

\section{Daftar Pustaka}

Aris. (2011). Gambaran kecemasan pasien gagal ginjal kronis yang menjalani hemodialisa di RSUD dr. Slamet Garut. Skripsi : Stikes Karsa Husada Garut.

Arsin, S., Mardiyono, M., \& Saryono, S (2007). Pemanfaatan terapi musik untuk meningkatkan status kesadaran pasien trauma kepala berat. Jurnal Keperawatan Soedirman (JKS).

Ayashi, E. S. (2012). Dahsyatnya senyuman ibadah super mudah manfaat super hebat. Jakarta: Qultum Media.
Benson, H. ( 2000). The relaxation response. Harper Collins. ISBN 0-380-81595-8.

Bherking \& Whitley. (2008). Affect regulation training: A practitioner's. New York London: Springer.

Catherine \& King, J. D. (2013). Problem Solved Anxiety. Prevention, 65 (11), 62.

Cukor, D., Coplan, J., Brown, C., \& Friedman, S. (2008). Anxiety disorders in adults treated by hemodialysis. Clinical Journal of the American Society of Nephrology: CJASN: 52(1), 128-136. doi:10.1053/j. ajkd.2008.02.300.

De Sousa, A. (2008). Psychiatric issues in renal failure and dialysis. Indian Journal of Nephrology,18(2), 47-50. doi:10.4103/09714065.42337.

Finnegan, J., Jennifer, T., \& Veronica, J. (2013). The psychosocial experience of patients with end-stage renal disease and its impact on quality of life: findings from a needs assessment to shape a service. ISRN Nephrology, 308986. doi:10.5402/2013/308986

Greenberg, J.S.(2002). Comprehensive stress management. (7th ed) New York: McGraw Hill Companies.

John, D., \& Gregory, F. (2013). The development of a patient-centered program based on the relaxation response: The relaxation response resiliency program (3RP). Psychosomatics, 54, 165-174.

Kaplan, B., \& Sadock, V. (2003). Kaplan and Sadock's synopsis of psychiatry: Behavioral Sciences/Clinical Psychiatry. (9th ed.). Philadelphia: Lippincott Williams \& Wilkins.

Kristen, L. M., \& Nola, A. S. (2004). Spiritual care in nursing practice.

Lee-Ellen, C. C-K., \& Banasikm J. L. Pathophysiology (text only) (4th ed.).

Mahdavi, A., Gorji, M. A. H., Gorji, A. M. H., Yazdani, J., \& Ardebil, M. D. (2013). 
Iin Patimah: Pengaruh Relaksasi Dzikir terhadap Tingkat Kecemasan Pasien Gagal Ginjal

Implementing benson's relaxation training in hemodialysis patients: Changes in perceived stress, anxiety, and depression. North American Journal of Medical Sciences,5(9), 536-40. doi:10.4103/1947-2714.118917.

Mardiyono, M., Songwathana, P., and Petpichetchian, W. (2011). Spirituality intervention and outcomes: Corner stone of holistic nursing practise. Nurse Media Journal of Nursing, 1(1):117-127.

Mauk \& Schmidt (2004). Spriritual care and nursing practice. USA: Lippincott Williams \& Wilkins.

Newberg. A., \& Waldman, M. (2013). Born To Believe: Gen iman dalam otak. (Alih Bahasa Nukman, E. F.). Bandung: Mizan.

Nuraeni, A. (2011). Eksplorasi makna spiritualitas pada klien dengan sindrom koroner akut yang menjalani perawatan di ruang intensif jantung RSUP Dr. Hasan Sadikin Bandung. Thesis program pasca sarjana fakultas Ilmu Keperawatan Unpad: Bandung.

Paloş, R., \& Loredana, V. (2014). Automatic negative thoughts and unconditional selfacceptance in rheumatoid arthritis: A preliminary study. ISRN Otolaryngology, $1-5$.

Potter, P. A., \& Perry, A. G. (2005). Buku ajar fundamental keperawatan: Konsep, proses, dan praktik (Ed. 4, Vol. 2). (Alih Bahasa Komalasari, R., dkk.). Jakarta: EGC.

Santoso (2005). Gagal Ginjal Kronik. diunduh melalui http://www.antiloans.org pada 25 Agustus 2014.

Smeltzer, S., \& Bare, B. (2002). Keperawatan medikal bedah bruner \& suddarth. (Ed. 8) (Alih Bahasa Pakaryaningsih E. M. Jakarta: EGC.
Soliman, H. (2013). Effects of zikr meditation and jaw relaxation on postoperative pain, anxiety and physiologic response of patients undergoing abdominal surgery, Journal of Biology Agriculture and Healthcare 3(2), 23-38.

Stuart, G.W \& Sundeen. (2006). Principles and practice of psychiatric nursing. St. Louis, Mosby: Elsevier.

Subandi, M. A. (2009). Psikologi dzikir . Yogyakarta: Pustaka Pelajar.

Sukaca, (2014). The 9 golden habits for brighter muslim: Meraih masa depan gemilang demi masa depan hebat. Yogyakarta Sleman: PT Bentang Pustaka.

Suryani, (2013) Shalat and dhikr to dispell voices: The experience of indonesian muslim with chronic mental illness: Malaysian Journal Publish Online Early.

Wang, L., \& Chen, C. (2009). The psychological impact of hemodialysis on patients with chronic renal failure. Departement of Psychiatry Chang Gung Memorial Hospital : Taiwan.

Yamamoto K, Nagata S. (2011). Physiological and psychological evaluation of the wrapped warm footbath as a complementary nursing therapy to induce relaxation in hospitalized patients with incurable cancer: A pilot study. Cancer Nurs. May-Jun;34(3):185-92. doi: 10.1097/NCC.0b013e3181fe4d2d.

Yanti, N. (2012). Perbandingan efektifitas terapi zikir dengan relaksasi benson terhadap kadar glukosa darah pasien diabetes melitus di sumatera barat. Universitas Indonesia. 